Arab Univ. J. Agric. Sci., Ain Shams Univ., Cairo, Egypt

27(3), 1929-1936, 2019

Website: http://ajs.journals.ekb.eg

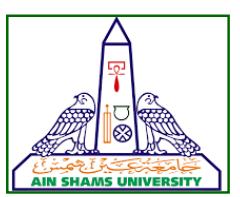

1929

\title{
EFFECT OF GROWTH REGULATOR NAA AND IBA APPLICATIONS ON TOTAL PHENOLIC AND FLAVONOID COMPOUNDS EXTRACTED FROM IN VITRO PRODUCED CALLUS OF CHICORY PLANT (Cichorium intybus L.)
}

\author{
Marwa, Othman*, Laila M. Helmi and Hosni A.M. \\ Horticulture Dept., Fac. of Agric., Ain Shams Univ., P.O. Box 68, Hadayek Shoubra 11241, \\ Cairo, Egypt \\ *Corresponding author: marwaplant@agr.asu.edu.eg
}

Received 29 July, 2019

Accepted 26 August, 2019

\section{ABSTRACT}

This research study was carried out in the plant tissue culture laboratory of the Agricultural Botany Department, Faculty of Agriculture, Ain Shams Univ., Shoubra El-khaima, Cairo, Egypt. Experiments were executed for the duration of two consecutive years 2017 and 2018 on chicory plant. Chicory (Cichorium intybus L.), which belongs to Asteraceae family, is considered as an important medicinal plant due to the presence of many bioactive substances such flavonoids, phenolic compounds, alkaloids, steroids, terpenoids, including (coumarines, cichoriin, esculetin, inulin, sesquiterpene lactones, chicoric acid, caffeic acid and some vitamins). In this research in vitro experiments were carried out using full strength Murashige and Skoog basal medium (MS) supplemented with different combinations of two plant growth regulators; Indole-3-butyric acid (IBA) including two concentrations $(0.5-2.0 \mathrm{mg} / \mathrm{l})$ and Naphthalene acetic acid (NAA) comprising four concentrations $(0.5-2.0-$ $3.0-5.0 \mathrm{mg} / \mathrm{l}$ ). An abaxially (lower side) leaf explants (square pieces $0.5 \times 0.5 \mathrm{~cm}$ ) which were taken from 20 days old aseptic chicory seedlings were inoculated to (MS) surface. Initially, chicory seeds were aseptically germinated on half-strength MS medium, after surface sterilization by $70 \%$ $(\mathrm{v} / \mathrm{v})$ ethanol for 60 seconds then soaking in $10 \%$ Clorox $(0.5 \%$ sodium hypochlorite $\mathrm{NaOCl})$ for 10 min to produce the aseptic chicory seedlings which were the source of true leaf explants used in this research study. Total phenolic compounds and flavonoids content were extracted from six-week $C$. intybus friable callus produced under both light and dark in vitro culture conditions inside a growth chamber incubation room where temperature was adjusted at $25^{\circ} \mathrm{C} \pm 1$. Total phenolic compounds and flavonoids were determined by spectrophotometric methods. The highest values for their contents were from chicory calli when MS callus induction medium was supplemented with $2 \mathrm{mg} / \mathrm{l}$ NAA under total dark condition when compared with the other remaining growth regulator treatment combinations and alternative light regime conditions.

Keywords: Cichorium intybus, NAA, IBA, Callus, Phenolic compounds, Flavonoids

\section{INTRODUCTION}

Most plant species in the plant kingdom particularly higher plants can produce bioactive compounds, which can play a serious role in human health (Castro et al 2016). Medicinal plants are the main best source of industrial and bioactive medicinal materials which are referred to sometimes as plant secondary metabolites that can be used in food, pharmaceutical, and cosmetic industries (Eshun \& He, 2004 and Khan \& Abourashed, 2011). Plant secondary metabolites can be used without harm as food additives (flavors, fragrances, sweeteners, colorants and food preservatives), nutraceuticals, and pharmaceuticals (Smetanska, 2008).

Tissue culture methods have gained more attention nowadays as an applicable safe and reliable technology to produce plant metabolites especially secondary metabolites (Zhong, 2001). This is because tissue culture techniques have many advantages for production of plant metabolites by offering a defined production system with continu- 
ous supply of metabolites, typical quality and quantity in short culture periods free of diseases and are not exposed to seasonal, geographical and environmental factors. Furthermore, new metabolites are produced in vitro by tissue cultures which aren't usually produced inside mother plant grown in the field (Sasson, 1992). Plant secondary metabolites can be produced in vitro by callus, cell suspension, organ and hairy roots cultures (Bourgaud et al 2001).

Chicory, (Cichorium intybus L.) is a plant member of the Aster family, (Asteraceae formerly known as the Compositae Family), that also involves Artichoke, Cornflower, Dandelion, Calendula, Sow thistle and Echinacea (Bais and Ravishankar, 2001). It is indigenous to Europe, Western Asia, Egypt, North America, and Italy easily identified by its light sky-blue flowers (Clapham et al 1962). Cichorium intybus L. has many common English names including blue daisy, blue sailors, blue weed, coffee-weed, common chicory, succory, bunk (Mitich, 1993). Historically, chicory was grown by the ancient Egyptians as a medical plant, leafy vegetable, and for animal feed (Greive, 1971). Moreover, chicory is all well known in Arabic and Islamic culture and is named as "hindiba" and "seris" in the Arabic language (Sari, 2007).

Medical importance of the chicory plant is attributed to its containment of many important metabolites such as flavonoids, phenolic compounds, alkaloids, steroids, terpenoids, including (coumarines cichoriin, esculetin, inulin, sesquiterpene lactones, chicoric acid, caffeic acid and vitamins), (Gonzalez, 1977; Rees \& Harborne, 1985 and Abbas et al 2015). Knowingly, all parts of chicory plant were usually used from ancient times until now to treat different symptoms and ailments like liver disorders, kidney, digestive, urinary disorders, gallstones, cholesterol, diabetes, jaundice, tumors, wound healing and as a blood purifier etc. (Duke, 1983 and Street et al 2013). Chicory in vitro callus cultures can provide the drug and food industry with many of in demand secondary metabolites under controlled conditions in a continuous manner as was mentioned by Malarz et al (2005). Therefore, the objective of this research study was to produce some secondary metabolites (total phenolic and flavonoids compounds) from chicory plant (Cichorium intybus L.) through in vitro callus culture.

\section{MATERIALS AND METHODS}

\section{Location and Duration}

This research study was carried out in the plant tissue culture laboratory of the Agricultural Botany Department, Faculty of Agriculture, Ain Shams University, Shoubra El-khaima, Cairo, Egypt. Experiments were performed for the duration of two consecutive years 2017 and 2018.

\section{Plant Materials}

Chicory seeds were collected from a plant well defined morphologically and grown in the open field in the Province of Al-Qalyubiya in June 2016. The collected seeds were incubated in a sealed jar and kept inside a fridge $\left(4: 5^{\circ} \mathrm{C}\right)$. These seeds were used to produce aseptic seedlings as was described by Nandagopal and Ranjitha Kumari (2006).

\section{Surface Sterilization of Initial Explants}

Seeds were surface cleaned by washing in running tap water several times. Then, they were washed in a solution of liquid detergent $1 \%(\mathrm{v} / \mathrm{v})$ for 5 minutes, subsequently rinsed for several times by distilled water. After thorough washing, the seeds were taken into the laminar flow cabinet and soaked for 60 seconds in $70 \%(\mathrm{v} / \mathrm{v})$ ethanol in small petri dishes then sterilized by soaking in $10 \%$ Clorox $(0.5 \%$ sodium hypochlorite $\mathrm{NaOCl})$ for 10 min (Babaei et al 2013). Thereafter, the sterile seeds were rinsed 3-5 times in autoclaved distilled water. They were aseptically germinated on halfstrength Murashige and Skoog (MS) medium (Murashige and Skoog, 1962) for 20 days (Malarz et al 2005 and Abdin \& Ilah, 2007).

\section{Callus Induction}

Full-strength MS basal medium (Caisson Labs company, USA) supplemented with combinations of Naphthalene acetic acid (NAA) concentrations $(0.5-2.0-3.0-5.0 \mathrm{mg} / \mathrm{l})$ and Indole-3-butyric acid (IBA) concentrations $(0.5-2.0 \mathrm{mg} / \mathrm{l})$ was used for callus induction. Then, the MS basal medium provided with $30 \mathrm{~g} / \mathrm{l}$ sucrose was adjusted to $\mathrm{PH}$ 5.7 and solidified with $0.7 \%(\mathrm{w} / \mathrm{v})$ agar (B\&V 


\section{Effect of growth regulator NAA and IBA applications on total phenolic and flavonoid compounds extracted from in vitro produced callus of chicory plant (Cichorium intybus L.)}

srl-parma company, Italy). The medium was dispensed into glass jars $(100 \mathrm{ml})$ containing $25 \mathrm{ml}$ of medium (Table, 1), then the media were autoclaved at $121^{\circ} \mathrm{C}$ for 20 minutes for sterilization. Explants used in this research study for in vitro callus production were true leaves taken from 20 days old sterile seedlings resulting from in vitro seed germination (Rehman et al 2003). Then, these leaves were cut into square pieces $(0.5 \times 0.5$ $\mathrm{cm})$ under aseptic conditions inside the laminar flow cabinet. The leaf explants were abaxial inoculated separately in 5 explants per jar on the surface of medium. Finally, media were incubated for six weeks under continuous light or total dark conditions at $25^{\circ} \mathrm{C} \pm 1$ (Nandagopal and Kumari, 2007).

Table 1. Summary of in vitro callus induction treatments and their abbreviated codes

\begin{tabular}{|c|c|l|}
\hline No. & Code & Specific treatments definition \\
\hline $\mathbf{1}$ & T1 & NAA $0.5 \mathrm{mg} / \mathrm{l}+\mathrm{IBA} 0.5 \mathrm{mg} / \mathrm{l}$ \\
$\mathbf{2}$ & T2 & NAA $3 \mathrm{mg} / \mathrm{l}+\mathrm{IBA} 2 \mathrm{mg} / \mathrm{l}$ \\
$\mathbf{3}$ & T3 & NAA $5 \mathrm{mg} / \mathrm{l}+\mathrm{IBA} 2 \mathrm{mg} / \mathrm{l}$ \\
$\mathbf{4}$ & T4 & NAA $2 \mathrm{mg} / \mathrm{l}$ \\
$\mathbf{5}$ & T5 & NAA 3mg/l \\
\hline
\end{tabular}

Note: two different types of synthetic auxin, Naphthalene acetic acid (NAA) and Indole-3-butyric acid (IBA) were used.

\section{Chemical Analyses}

From samples of the six-week $C$. intybus friable calli produced in vitro, internal chemical components were determined for the following:

- Total phenolic compounds by a spectrophotometric method according to Singleton and Rossi (1965).

- Total flavonoids according to the method described by Nagy and Grancai (1996).

\section{Experimental Design and Statistical Analysis}

All experiments were arranged in a completely randomized design with five replicates for each treatment. Each replicate contained one jar and each jar contained five explants. Experiments included two factors: first factor was induction chemical treatments and, second factor was light condition during induction continuous light and dark. Duncan's multiple-range test at probability level of $5 \%$ was employed for mean comparisons according to Duncan (1955).

\section{RESULTS AND DISCUSSION}

Friable calli formation were observed after 7 days from the inoculation of chicory leaf explants onto callus induction media (Malarz et al 2005). Six-week calli were collected and extracted to determine phenolic compounds and flavonoids.

Result data presented in Table (2) show that the differences among treatments were significant in general. Regarding the effect of auxin treatments, the differences were not significant, except with T4 (NAA 2mg/l) which gave a higher value (0.262 and $0.292 \mathrm{mg} / \mathrm{g}$ ) when compared to T3 (NAA $5 \mathrm{mg} / \mathrm{l}+$ IBA $2 \mathrm{mg} / \mathrm{l})$ which was lower $(0.193$ and $0.215 \mathrm{mg} / \mathrm{g}$ ) in the years 2017 and 2018, in respect order. As for the effect of light conditions, the differences were not significant between light and dark. As for the effect of the interaction between auxin and light condition treatments, results revealed significant differences amongst treatments, the highest value being T4 (NAA 2mg/l) under dark conditions ( 0.269 and $0.299 \mathrm{mg} / \mathrm{g}$ ) for both years 2017 and 2018 respectively when compared with the remaining combinations.

Result data displayed in Table (3) indicate that the differences among treatments in total flavonoids content were significant in general. Regarding the effect of auxin treatments only, the differences were also significant, but the higher value was T4 (NAA 2mg/l). With regards the effect of light conditions, the differences were not significant. Finally, the effect of the interaction between auxin treatments and light conditions treatments revealed significant differences, and the highest value was T4 (NAA $2 \mathrm{mg} / \mathrm{l})$ under dark conditions for both two years.

Results obtained here agree with Kumari et al (2007) who used MS medium supplemented with 2 $\mathrm{mg} / \mathrm{l} \mathrm{NAA}$ to produce secondary metabolites like esculin from chicory callus. Boeuf et al (2001) also obtained friable callus from $C$. intybus mature root explants by using Heller's medium (Heller, 1953) supplemented with NAA concentrations (2 - 0.2 $\mathrm{mg} / \mathrm{l})$ in vitro culture and measured proteins and peroxidase activity enzyme. However, green compact callus was developed on MS medium fortified with $0.1-2.0 \mathrm{mg}$ IBA and NAA in combination with $0.5 \mathrm{mg} / \mathrm{l}$ BAP in leaf, cotyledon, hypocotyl, and root of $C$. intybus explants as tested by Velayutham et al (2006). Shilpa and Lakshmi (2019) reported that total phenol content and chlorogenic acid could be extracted from $C$. intybus calli that were produced from chicory young leaf explants inoculated on MS medium with varied combinations of NAA and kinetin (KIN). 
Table 2. Effect of auxin type and concentration on total phenolic compounds extracted from friable callus produced in dark and light by in vitro culture from leaf explants of Chicory (Cichorium intybus $\mathrm{L}$.) in two years (2017 and 2018)

\begin{tabular}{|c|c|c|c|c|}
\hline \multicolumn{5}{|c|}{2017} \\
\hline \multirow{2}{*}{ Auxin treatments } & \multirow{2}{*}{ Treatment code } & \multicolumn{3}{|c|}{ Total phenolic compounds (mg/g) } \\
\hline & & Light & Dark & mean \\
\hline NAA $0.5 \mathrm{mg} / \mathrm{l}$ + IBA $0.5 \mathrm{mg} / \mathrm{I}$ & T1 & $0.224 \mathrm{ABCD}$ & $0.236 \mathrm{ABC}$ & $0.230 \mathrm{AB}$ \\
\hline NAA 3mg/l + IBA 2mg/l & T2 & $0.211 \mathrm{BCD}$ & $0.222 \mathrm{BCD}$ & $0.217 \mathrm{AB}$ \\
\hline NAA $5 \mathrm{mg} / \mathrm{l}$ + IBA $2 \mathrm{mg} / \mathrm{l}$ & T3 & $0.188 \mathrm{D}$ & $0.198 \mathrm{CD}$ & $0.193 \mathrm{~B}$ \\
\hline NAA 2mg/l & T4 & $0.256 \mathrm{AB}$ & $0.269 \mathrm{~A}$ & $0.262 \mathrm{~A}$ \\
\hline \multirow[t]{2}{*}{ NAA 3mg/l } & T5 & $0.216 \mathrm{BCD}$ & $0.227 \mathrm{ABCD}$ & $0.222 \mathrm{AB}$ \\
\hline & Mean & $0.219 \mathrm{~A}$ & $0.231 \mathrm{~A}$ & \\
\hline \multicolumn{5}{|c|}{2018} \\
\hline \multirow{2}{*}{ Auxin treatments } & \multirow{2}{*}{ Treatment code } & \multicolumn{3}{|c|}{ Total phenolic compounds (mg/g) } \\
\hline & & Light & Dark & mean \\
\hline NAA $0.5 \mathrm{mg} / \mathrm{l}+$ IBA $0.5 \mathrm{mg} / \mathrm{l}$ & T1 & $0.243 \mathrm{~A}$ & $0.256 \mathrm{~A}$ & $0.255 \mathrm{AB}$ \\
\hline NAA 3mg/l + IBA 2mg/l & T2 & $0.235 \mathrm{CD}$ & $0.247 \mathrm{BCD}$ & $0.241 \mathrm{AB}$ \\
\hline NAA $5 \mathrm{mg} / \mathrm{l}$ + IBA $2 \mathrm{mg} / \mathrm{l}$ & T3 & $0.209 \mathrm{D}$ & $0.220 \mathrm{CD}$ & $0.215 \mathrm{~B}$ \\
\hline NAA 2mg/l & T4 & $0.284 \mathrm{AB}$ & $0.299 \mathrm{~A}$ & $0.292 \mathrm{~A}$ \\
\hline \multirow[t]{2}{*}{ NAA 3mg/l } & T5 & 0.240 BCD & $0.253 \mathrm{ABCD}$ & $0.246 A B$ \\
\hline & Mean & $0.243 \mathrm{~A}$ & $0.256 \mathrm{~A}$ & \\
\hline
\end{tabular}

Values in the same column followed by the same letter(s) are not statistically different according to Duncan's multiple range test (Duncan, 1955).

Table 3. Effect of auxin type and concentration on total flavonoids extracted from friable callus produced in dark and light by in vitro culture from leaf explants of Chicory (Cichorium intybus L.) in two years (2017 and 2018)

\begin{tabular}{|c|c|c|c|c|}
\hline \multicolumn{5}{|c|}{2017} \\
\hline \multirow{2}{*}{ Auxin treatments } & \multirow{2}{*}{ Treatment code } & \multicolumn{3}{|c|}{ Total flavonoids (mg/g) } \\
\hline & & Light & Dark & mean \\
\hline NAA $0.5 \mathrm{mg} / \mathrm{l}+$ IBA $0.5 \mathrm{mg} / \mathrm{l}$ & T1 & $0.157 \mathrm{ABC}$ & $0.165 \mathrm{ABC}$ & $0.161 \mathrm{AB}$ \\
\hline NAA $3 \mathrm{mg} / \mathrm{l}+$ IBA $2 \mathrm{mg} / \mathrm{l}$ & T2 & $0.148 \mathrm{ABC}$ & $0.156 \mathrm{ABC}$ & $0.152 \mathrm{AB}$ \\
\hline NAA 5mg/l + IBA 2mg/l & T3 & $0.132 \mathrm{C}$ & $0.139 \mathrm{BC}$ & $0.135 \mathrm{~B}$ \\
\hline NAA 2mg/l & T4 & $0.179 \mathrm{AB}$ & $0.188 \mathrm{~A}$ & $0.184 \mathrm{~A}$ \\
\hline \multirow[t]{2}{*}{ NAA $3 \mathrm{mg} / \mathrm{l}$} & T5 & $0.151 \mathrm{ABC}$ & $0.159 \mathrm{ABC}$ & $0.155 \mathrm{AB}$ \\
\hline & Mean & $0.153 \mathrm{~A}$ & $0.161 \mathrm{~A}$ & \\
\hline \multicolumn{5}{|c|}{2018} \\
\hline \multirow{2}{*}{ Auxin treatments } & \multirow{2}{*}{ Treatment code } & \multicolumn{3}{|c|}{ Total flavonoids (mg/g) } \\
\hline & & Light & Dark & mean \\
\hline NAA $0.5 \mathrm{mg} / \mathrm{I}+$ IBA $0.5 \mathrm{mg} / \mathrm{l}$ & T1 & $0.174 \mathrm{ABC}$ & $0.183 \mathrm{ABC}$ & $0.179 \mathrm{AB}$ \\
\hline NAA 3mg/l + IBA 2mg/l & T2 & $0.164 \mathrm{ABC}$ & $0.173 \mathrm{ABC}$ & $0.169 \mathrm{~B}$ \\
\hline NAA 5mg/l + IBA 2mg/l & T3 & $0.147 \mathrm{C}$ & $0.154 \mathrm{BC}$ & $0.151 \mathrm{~B}$ \\
\hline NAA 2mg/l & T4 & $0.199 \mathrm{AB}$ & $0.209 \mathrm{~A}$ & $0.204 \mathrm{~A}$ \\
\hline \multirow[t]{2}{*}{ NAA 3mg/l } & T5 & $0.168 \mathrm{ABC}$ & $0.177 \mathrm{ABC}$ & $0.173 \mathrm{AB}$ \\
\hline & Mean & $0.170 \mathrm{~A}$ & $0.179 \mathrm{~A}$ & \\
\hline
\end{tabular}

Values in the same column followed by the same letter(s) are not statistically different according to Duncan's multiple range test (Duncan, 1955). 


\section{Effect of growth regulator NAA and IBA applications on total phenolic and flavonoid compounds extracted from in vitro produced callus of chicory plant (Cichorium intybus L.)}

Al Khateeb et al (2012) found that MS medium with NAA plus 6-Benzylaminopurine (BAP) (0.5: $2.0 \mathrm{mg} / \mathrm{l})$ can produce callus from chicory young leaf explants and was able to obtain high amount of phenolic compounds from it.

Other growth regulators such as 2,4dichlorophenoxyacetic acid (2,4-D) plus kinetin $(1 \mathrm{mg} / \mathrm{l}+0.3 \mathrm{mg} / \mathrm{l}$ in order) added to MS medium were used by Malarz et al (2005) to initiate chicory callus in vitro from leaf explants and isolate three new and one known furofuran lignans. In addition, 2, 4-D (0.5-1.0 $\mathrm{mg} / \mathrm{l})$ alone or in combination with BAP $(0.5-1.0 \mathrm{mg} / \mathrm{l})$ were added to MS medium to induct callus from chicory leaf, stem and bud explants and led to increase total phenolics and flavonoids content (Verma et al 2012).

In this study, synthetic auxins IBA and NAA were used in aseptic culture systems to induce and stimulate callus formation. Their use in inducing callus were established quite a long time ago. The common practice of using synthetic auxins such as IBA or NAA as substitutes for naturally 3 -indole acetic acid (IAA) was shown to be more effective for certain purposes such as inducing callus (Bonga, 1982). The promoting effects of auxins could be interpreted by their mechanisms to cause cell enlargement, cell elongation and loosening cell walls within a few minutes after application by modification of cell membranes (Wareing and Phillips 1970 and Kevers et al 1981).

It is worth mentioning that, Phenolics are secondary plant metabolites that are ubiquitously present in plants and their products (Razali et al 2008). Flavonoids are one of the largest classes of plant phenolics. Plant phenolics are biosynthesized by several different routes and thus constitute a heterogeneous group from a metabolic point of view. Two basic pathways are involved: the shikimic acid pathway and the malonic acid pathway. In higher plants, most phenolics are derived at least in part from phenylalanine, a product of the shikimic acid pathway. Phenylalanine is an intermediate in the biosynthesis of most plant phenolics. Synthetic auxins such as NAA and IBA are also derived from phenylalanine, tyrosine, or tryptophan as aromatic amino acids (Taiz and Zeiger, 2002).

Physiologically, auxins are known to trigger their effects through affecting some steps in protein synthesis or by affecting enzyme activity (Wareing \& Phillips, 1970 and Leopold \& Kriedemann, 1975). Synthetic auxins like IBA and NAA produce effects similar to those which IAA (the natural auxin) itself elicits (Wareing and Phillips, 1970). One possibility to interpret results obtained here could be that auxins applied exogenously may have exerted an effect by affecting phenylalanine ammonia-lyase (PAL) which is an enzyme considered as a precursor for the various phenolic and flavonoid compounds by initially forming cinnamic acid in the process (Dey \& Harborne, 1997; Heldt, 1997 and Taiz \& Zeiger, 2002).

\section{REFERENCES}

Abbas Z.K., Saggu S., Sakeran M.I., Zidan N., Rehman H. and Ansari A.A. 2015. Phytochemical, antioxidant and mineral composition of hydroalcoholic extract of chicory (Cichorium intybus L.) leaves. Saudi J. of Biological Sci., 22(3), 322-326.

Abdin M.Z. and Ilah, A. 2007. Plant regeneration through somatic embryogenesis from stem and petiole explants of Indian chicory (Cichorium intybus L.). Indian J. of Biotechnology 6(2), 250-255.

Al-Khateeb W., Hussein E., Qouta L., Alu'datt M., Al-Shara B. and Abu-Zaiton A. 2012. In vitro propagation and characterization of phenolic content along with antioxidant and antimicrobial activities of Cichorium pumilum Jacq. Plant Cell, Tissue and Organ Culture 110(1), 103-110.

Babaei N., Abdullah N.A.P., Saleh G. and Abdullah T.L. 2013. Control of contamination and explant browning in Curculigo latifolia in vitro cultures. J. of Medicinal Plants Research, 7(8), 448-454.

Bais H.P. and Ravishankar G.A. 2001. Cichorium intybus L-cultivation, processing, utility, value addition and biotechnology, with an emphasis on current status and future prospects. $\mathbf{J}$. of the Sci. of Food and Agric., 81(5), 467-484.

Boeuf G., Roszak, R., Legrand, B., and Rambour, S. 2001. Effect of NAA on the development, apoplastic peroxidase activities, and peroxidase isoenzymes in chicory root explants. J. of Plant Physiology, 158(8), 963-969.

Bonga J.M. 1982. Tissue culture techniques. In: Tissue Culture in Forestry Bonga J.M. and Durzan D.J. Eds., Springer, Dordrecht, Vol. 5, pp. 4-35.

Bourgaud F., Gravot A., Milesi S. and Gontier E. 2001. Production of plant secondary metabolites: a historical perspective. Plant Sci., 161(5), 839-851. 
Castro A.H.F., Braga K.D.Q., Sousa F.M.D., Coimbra M.C. and Chagas R.C.R. 2016. Callus induction and bioactive phenolic compounds production from Byrsonima verbascifolia (L.) DC. (Malpighiaceae). Revista Ciência Agronômica, 47(1), 143-151.

Clapham A.R., Tutin T.G. and Warburg E.F. 1962. Flora of the British Isles. Cambridge University Press, U.K., 720 p.

Dey P.M. and Harborne J.B. 1997. Plant biochemistry. Elsevier Academic press, U.S.A., $554 \mathrm{p}$.

Duke J.A. 1983. Medicinal plants of the Bible. Trado-Medic Books, London, U.K., pp. 97-104.

Duncan D.B. 1955. Multiple range and multiple F tests. Biometrics, 11(1), 1-42.

Eshun K. and He Q. 2004. Aloe vera: a valuable ingredient for the food, pharmaceutical and cosmetic industries-a review. Critical Reviews in Food Sci. and Nutrition, 44(2), 9196.

Gonzalez A.G. 1977. Lactuceae chemical review. In: The Biology and Chemistry of the Compositae. Academic Press, London, U.K., pp. 10811095.

Greive M. 1971. A modern herbal. Dover publication, New York, U.S.A., 287 p.

Heldt, Hans-Walter 1997. Plant biochemistry and molecular biology. Oxford University Press, New York, U.S.A., 522 p.

Heller R. 1953. Recherches sur la nutrition minerales des tissues vegetaux cultives, in vitro. Ann. Sci. Nat. Bot. Biol. Veg., 14, 201- 223.

Kevers C., Coumans M., De Greef W., Hofinger M. and Gaspar T. 1981. Habituation in sugarbeet callus: auxin content, auxin protectors, peroxidase pattern and inhibitors. Physiologia Plantarum, 51(3), 281-286.

Khan I.A. and Abourashed E.A. 2011. Leung's encyclopedia of common natural ingredients: used in food, drugs and cosmetics. John Wiley and Sons, U.K., 848 p.

Kumari B.R., Velayutham P. and Anitha S. 2007. A comparitive study on inulin and esculin content of in vitro and in vivo Plants of Chicory (Cichorium intybus L. Cv. Lucknow Local). Advances in Biological Research, 1(1-2), 2225.

Leopold A.C. and Kriedemann P.E. 1975. Plant growth and development. McGraw-Hill, New York, U.S.A., 545 p.
Malarz J., Stojakowska A., Szneler E. and Kisiel W. 2005. Furofuran lignans from a callus culture of Cichorium intybus. Plant Cell Reports, 24(4), 246-249.

Mitich L.W. 1993. Chicory. Weed Technology, 7(1), 274-277.

Murashige T. and Skoog F. 1962. A revised medium for rapid growth and bio assays with tobacco tissue cultures. Physiologia Plantarum, 15(3), 473-497.

Nagy M. and Grancai D. 1996. Colorimetric determination of flavanones in propolis. Pharmazie, 51(2), 100-101.

Nandagopal S. and Ranjitha-Kumari B.D. 2006. Adenine sulphate induced high frequency shoot organogenesis in callus and in vitro flowering of Cichorium intybus L. cv. Focus-a potent medicinal plant. Acta Agric. Slovenica, 87(2), 415425.

Nandagopal S. and Kumari D.R. 2007. Effectiveness of auxin induced in vitro root culture in chicory. J. of Central European Agric., 8(1), 73-80.

Razali N., Razab R., Junit S.M. and Aziz A.A. 2008. Radical scavenging and reducing properties of extracts of cashew shoots (Anacardium occidentale). Food Chemistry, 111(1), 38-44.

Rees S.B. and Harborne J.B. 1985. The role of sesquiterpene lactones and phenolics in the chemical defence of the chicory plant. Phytochemistry, 24(10), 2225-2231.

Rehman R.U., Israr M., Srivastava, P.S., Bansal K.C. and Abdin M.Z. 2003. In vitro regeneration of witloof chicory (Cichorium intybus L.) from leaf explants and accumulation of esculin. In Vitro Cellular and Developmental Biology-Plant, 39(2), 142-146.

Sari N. 2007. Hindiba: A Drug for Cancer Treatment in Muslim Heritage. Foundation for Science, Technology and Civilisation Limited, U.K., pp. 1-40.

Sasson A. 1992. Production of useful biochemicals by higher-plant cell cultures: biotechnological and economic aspects. In: BiotechnologyEconomic and Social Aspects. Ed. Sasson A., Ratledge C. and Dasilva E.J., Cambridge Univ., Press, pp. 81-109.

Shilpa K. and Lakshmi B.S. 2019. Influence of exogenous cinnamic acid on the production of chlorogenic acid in Cichorium intybus $L$ cell culture. South African J. of Botany, (In press). 
Singleton V.L. and Rossi J.A. 1965. Colorimetry of total phenolics with phosphomolybdicphosphotungstic acid reagents. American J. of Enology and Viticulture, 16(3), 144-158.

Smetanska I. 2008. Production of secondary metabolites using plant cell cultures. In: Food biotechnology. Advances in Biochemical Engineering/Biotechnology. Springer, Berlin, Heidelberg, 111, 187-228.

Street R.A., Sidana J. and Prinsloo G. 2013. Cichorium intybus: Traditional uses, phytochemistry, pharmacology, and toxicology. Evidence-Based Complementary and Alternative Medicine, pp. 1-13.

Taiz L. and Zeiger E. 2002. Plant Physiology. $3^{\text {rd }}$. Sunderland, Mass: Sinauer Associates Inc., U.S.A., 690 p.

Velayutham P., Ranjithakumari B.D. and Baskaran P. 2006. An efficient in vitro plant regeneration system for Cichorium intybus L.-an important medicinal plant. J. of Agric. Technology, 2(2), 287-298.

Verma K., Sapra S., Bagga A. and Verma S. 2012. Comparison of various active ingredients between ex-situ and in-vitro grown plants of Withania somnifera L. and Cichorium intybus L. The Bioscan, an International Quarterly J. of Life Sci., 7(2), 347-351.

Wareing P.F. and Phillips I.D.J. 1970. The control of growth and differentiation in plants. Pergamon Press, Second ed, New York, U.S.A., $313 \mathrm{p}$.

Zhong J.J. 2001. Biochemical engineering of the production of plant-specific secondary metabolites by cell suspension cultures. In: Advances in Biochemical Engineering/ Biotechnology. Zhong J.J., and Scheper T. Eds., Springer, Berlin, Germany, Vol. 72, pp. 1-26. 


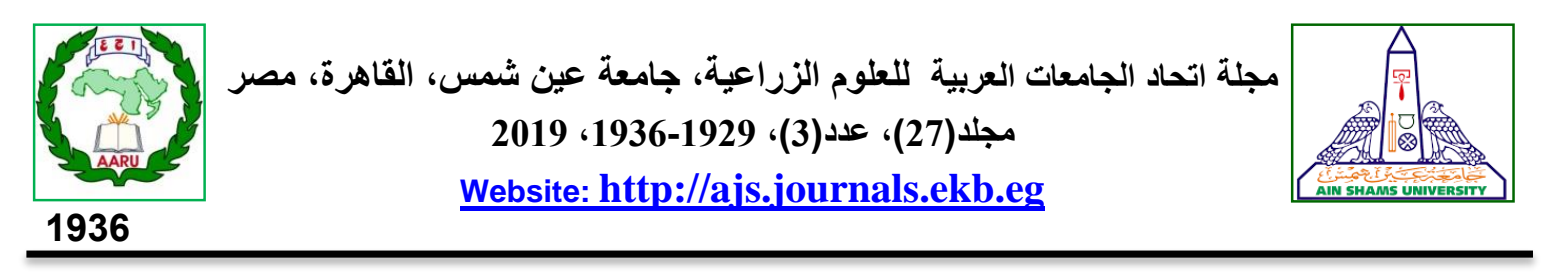

تأثير معاملات منظمات النمو NAA و IBA على مركبات الفينولات والفلافونات الكلية

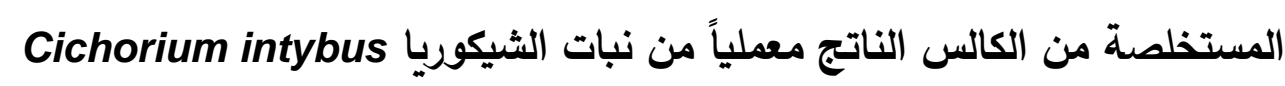

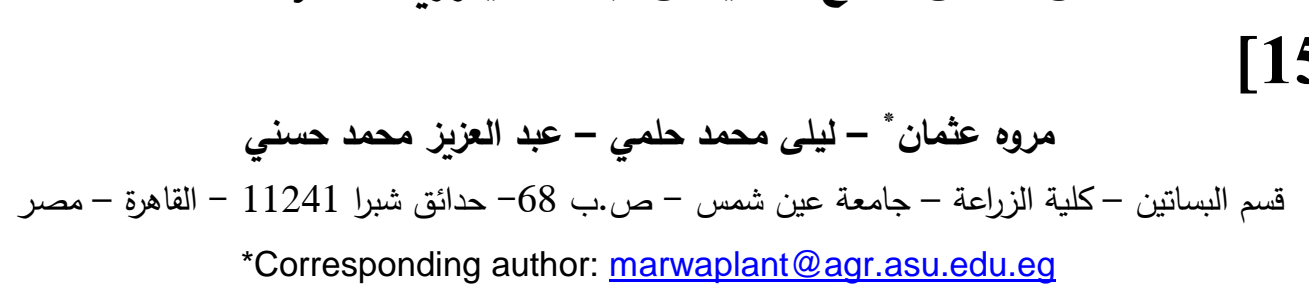

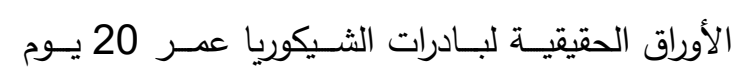

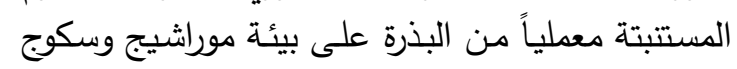

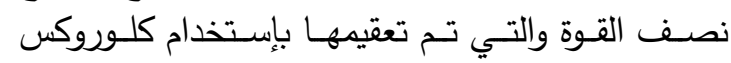

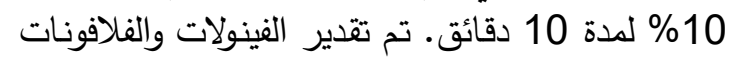
الكلية فى الكالس المفكك (عمر 6 أسابيع) الناتج تحت

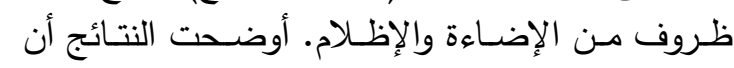

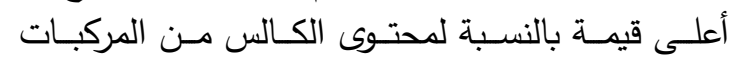

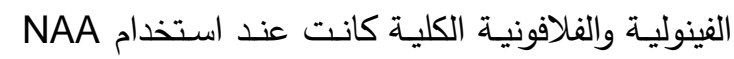
بتركيز 2 ملجم/لتر تحت ظروف الإظلام.

الكلمات الدالة: شيكوريا, Cichorium intybus, كالس, نفثالين حمض الخليك, إندول حمض البيوتيك, فيكرات فينولات, فلافونات فئن

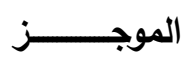

Cichorium يعتبر نبـات الثـيكوريا intybus

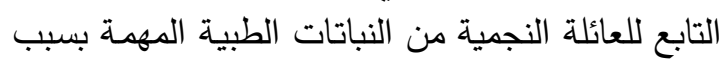

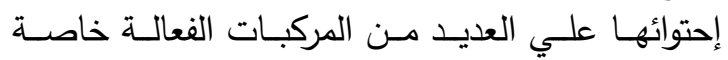

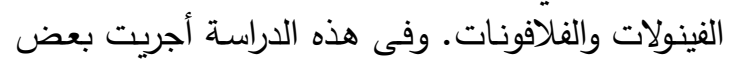

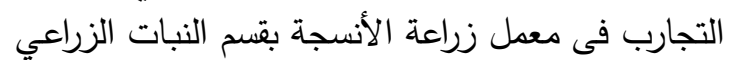

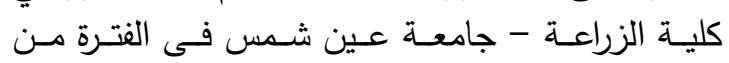

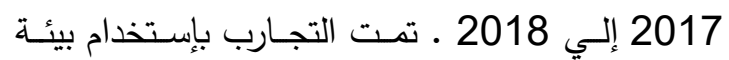
موراشيج وسكوج MS كاملة القوة مضـافاً إليها نوعين التين NAA من منظمات النمو وهما نفثالين حمض الخليك وإندول حمض البيوتريك IBA بتركيزات (0.5 - 2.0 - 3.0 - 5.0 ملجم/لتر ) و (0.5- 2.0 ملجم/تلتر )

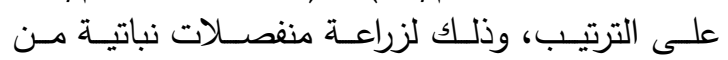

